INTERNATIONAL JOURNAL OF RESEARCHES IN BIOSCIENCES, AGRICULTURE AND TECHNOLOGY (C) VISHWASHANTI MULTIPURPOSE SOCIETY (Global Peace Multipurpose Society) R. No. MH-659/13(N) www.vmsindia.org

\title{
DETECTION OF CHANGES IN RAINFALL FOR IDENTIFYING CLIMATE CHANGE USING MANN-KENDALL TEST
}

\author{
Sandip Sasane
}

Department of Geography, Shivaji University, Kolhapur - 416004

\begin{abstract}
In present paper an attempt has been made to detect the long-term changes in the rainfall applying Mann-Kendall Test (MK). The rainfall data were collected for fourteen tahsil of Ahmednagar District from Indian Meteorological department (IMD), Pune. The result shows decreasing trends (Negative) in Shrirampur, Parner, Shrigonda, Karjat, Jamkhed and Nagar tahsil while, increasing trends in Akole, Sangamner, Kopergaon, Rahuri, Newasa, Rahata, Shevgaon and Pathardi tahsil of Ahmednagar District. This is wake call for southern tahsil, recorded declining rainfall trend. The result clearly shows that climate changed in Ahmednagar district during 1981 to 2011.
\end{abstract}

Keywords - Climate Change, Man-Kendall Test, Rainfall Trend

\section{Introduction}

Last few decades, climate change is emerging as a significant global man-made challenge. Climate Change refers to any change in climate over the time caused by naturally or anthropogenic response. Changes in major climate variables, such as rainfall may have long-term inferences in the quality and quantity of water, health, food security, agriculture and so many others sectors. Though it is very difficult to recognize the future trend of rainfall, it is possible to detect the nature of changes that occurred in the past. Mann-Kendall (MK) is one of the most commonly used non-parametric tests for detecting climatic changes in time series and trend analysis (Mann 1945; Kendall 1955). Determining the trends in the rainfall is extremely important because it may useful to detect climate change (Kale, 1999). Many Indian scholars investigated changes in rainfall for last five decades (Raghvendra V. K, 1974; Moonley and Parthasarathy, 1984: Alaka Gadagil, 1986; Parthasarathy et. al., 1991; Kripalani and Kulkarni, 1997, Kale V. S., 1999, Hire and Gunjal, 2006; Rathod, Muniyappa and Aruchamy S., 2010; Gatade and Sasane, 2015).

The object of the paper is, therefore, to detect the rainfall trend for identify climate change in Ahmednagar District during 1981 to 2011.

\section{Study Area}

Ahmednagar is the largest district of Maharashtra State with geographical area of 17 , 418 sq. km. (17. 41 lakh ha.) which is $5.66 \%$ of area of Maharashtra State. It lies between $18^{\circ} 2^{\prime}$ to $19^{\circ} 9^{\prime} \mathrm{N}$ latitude and $73^{\circ} 9^{\prime}$ to $75^{\circ} 5^{\prime} \mathrm{E}$ longitude with covering 14 tahsils. The population of district is $45,43,083$ (Provisional Census, 2011) and Out of total workers $75.42 \%$ are engaged in agriculture. The district has 12,
56,500 ha Net Cropped Area (NCA) out of 3, 30,000 ha area $(26.27 \%)$ is under canal and well irrigation and remaining about 9, 26,500 ha. $(73.73 \%)$ area is rain fed. Therefore agricultural operations are mainly depends on SW Monsoon, but rainfall in district is highly erratic. The average annual rainfall in the district is $568.7 \mathrm{~mm}$. The district is mostly in rain shadow region to the east of Western Ghats. From the western border of the district the rainfall decreases rapidly towards east. About $77 \%$ of the annual rainfall in the district is received during the SW monsoon season, September being the rainiest month and remaining months receiving unevenly with showing monthly as well as annual rainfall variability.

\section{Objective}

To detect changes in Rainfall of Ahmednagar District using Mann-Kendall Test for Identify Climate Change during 1981 to 2011.

\section{Database and Methodology}

The assessment of climate change in Ahmednagar district has been study in annual scale through the non-parametric Mann-Kendall (MK) test to detect changes in rainfall. Annual rainfall data of 14 raingauge stations of the Ahmednagar district for the period 1981 to 2011 was obtained from the Indian Meteorological Department (IMD), Pune. The Mann-Kendall test (Mann; 1945 and Kendall; 1975) is a nonparametric test for identifying trends in time series data which is widely used statistical test to determine whether there is a positive or negative trend in data with their statistical significance. 
Mann-Kendall (M-K) test statistic is defined as

$$
\begin{gathered}
S=\sum_{i=1}^{n-1} \sum_{j=i+1}^{n} \operatorname{sign}\left(T_{j}-T_{i}\right) \\
\operatorname{Sign}\left(T_{j}-T_{i}\right)=\left\{\begin{array}{c}
1 \text { if } T_{j}-T_{i}>0 \\
0 \text { if } T_{j}-T_{i}=0 \\
-1 \text { if } T_{j}-T_{i}<0
\end{array}\right.
\end{gathered}
$$

Sen's method was also used to determine the magnitude of the trends. The data values are evaluate as an ordered time series According to this test, the null hypothesis $\mathrm{HO}$ assumes that there is no trend and this is tested against the alternative hypothesis $\mathrm{H} 1$, which assumes that there is a trend.

\section{Result and Discussion}

In this research work, analysis of the rainfall data shows that mean annual rainfall varies from $186 \mathrm{~mm}$ in Rahata to $693 \mathrm{~mm}$ in Jamkhed. The standard deviation differs from $111.34 \mathrm{~mm}$ to $257.51 \mathrm{~mm}$ for Sangamner and Rahata, respectively.

With non parametric Mann-Kendall test, Trend of rain fall 31 year from 1981 to 2011 has been calculated individually with 14 tahsil of Ahmednagar district. With Sen's magnitude of slope in the Mann -Kendall's Test described trend, 0.45, 0.267, -0.086, 0.194, 0.148, $0.116,0.626,0.198,0.069,-0.245,-0.056$, $\mathbf{0 . 0 2 8},-\mathbf{0 . 0 3 9},-\mathbf{0 . 1 3 5}$, respectively (Fig. 1). Akole, Sangamner, Kopergaon, Rahuri, Newasa, Rahata, Shevgaon and Pathardi has been shown rising (Positive) a trend while Shrirampur, Parner, Shrigonda, Karjat, Jamkhed and Nagar indicated the fall trend (Negative). (Fig.2)

Table 1: Rainfall Trend Analysis of Ahmednagar district during 1981 to 2011

\begin{tabular}{|l|l|l|l|l|l|l|l|}
\hline $\begin{array}{l}\text { Sr. } \\
\text { No }\end{array}$ & Tehsils & Mean & SD & Mann-Kendall Trend test & $\begin{array}{l}\text { P } \\
\text { Value }\end{array}$ & Sen's slope & $\begin{array}{l}\text { Trends } \\
\text { at 5 \% } \\
\text { significance Level }\end{array}$ \\
\hline 1 & Akole & 574.32 & 249.48 & 0.45 & 1.00 & 14.400 & Positive Trend \\
\hline 2 & Sangamner & 412.181 & 111.346 & 0.267 & 0.982 & 5.029 & Positive Trend \\
\hline 3 & Shrirampur & 489.416 & 153.091 & -0.086 & 0.254 & -1.947 & Negative Trend \\
\hline 4 & Kopergaon & 467.394 & 134.437 & 0.194 & 0.935 & 4.385 & Positive Trend \\
\hline 5 & Rahuri & 531.355 & 154.841 & 0.148 & 0.882 & 3.900 & Positive Trend \\
\hline 6 & Newasa & 484.526 & 160.633 & 0.116 & 0.816 & 3.389 & Positive Trend \\
\hline 7 & Rahata & 186.903 & 257.513 & 0.626 & 1.00 & 16.048 & Positive Trend \\
\hline 8 & Shevgaon & 520.697 & 181.123 & 0.198 & 0.939 & 5.889 & Positive Trend \\
\hline 9 & Pathardi & 600.745 & 202.899 & 0.069 & 0.701 & 1.667 & Positive Trend \\
\hline 10 & Parner & 526.674 & 174.643 & -0.245 & 0.027 & -6.667 & Negative Trend \\
\hline 11 & Shrigonda & 482.684 & 121.093 & -0.056 & 0.335 & -0.571 & Negative Trend \\
\hline 12 & Karjat & 554.097 & 162.127 & -0.028 & 0.42 & -1.500 & Negative Trend \\
\hline 13 & Jamkhed & 693.339 & 226.762 & -0.039 & 0.386 & -1.667 & Negative Trend \\
\hline 14 & Nagar & 613.294 & 237.080 & -0.135 & 0.148 & -4.960 & Negative Trend \\
\hline
\end{tabular}

(Source: Computed by Researcher)

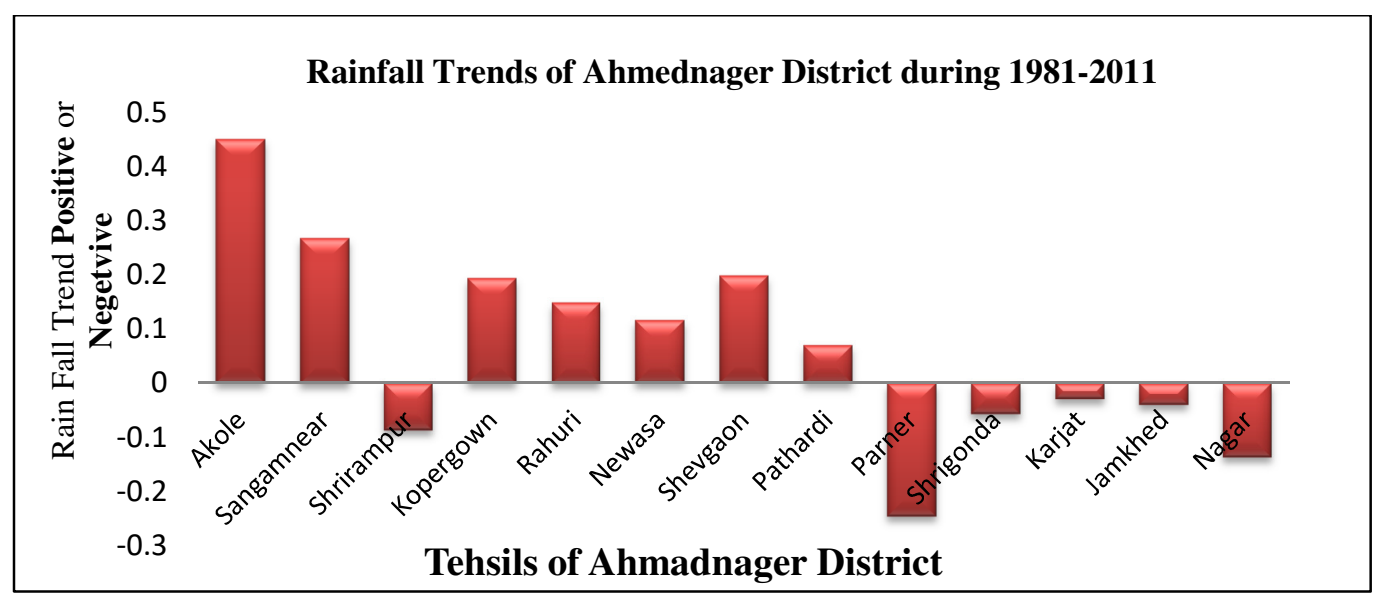

Figure 1: Rainfall Trends of Ahmednagar District during 1981-2011 
Rainfall Trend Analysis of Ahmednagar District during 1981 to 2011

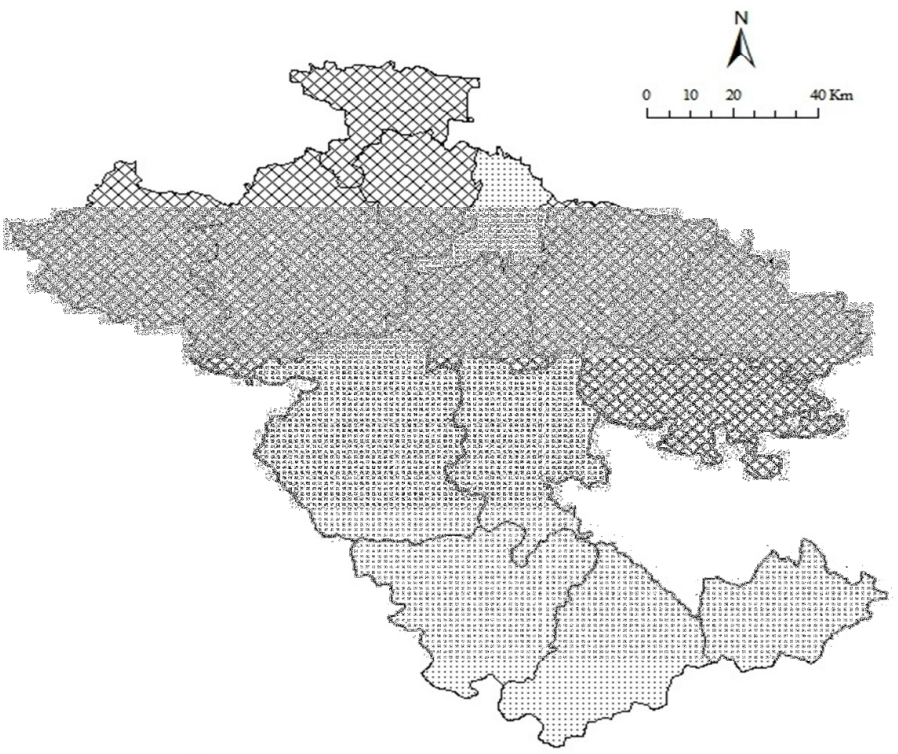

Legend

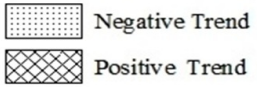

Figure 2: Rainfall Trends of Ahmednagar District during 1981-2011

\section{Conclusion}

The present paper focuses on trend of rainfall on fourteen stations by applying MannKendall Test. The present finding showed that Mann-Kendall Test (MK) have good capability for trend detection in Climatology time data series. Fig. 1 shows that there is a decreasing trend (-) in Shrirampur, Parner, Shrigonda, Karjat, Jamkhed and Nagar. It indicated that climate changed during the 1981 to 2011, alarming for southern part of district. Due to decline in rainfall, the quality and quantity of water, health, food security, agriculture and so many others sectors was affected. Where, increasing $(+)$ trend was recorded in Akole, Sangamner, Kopergaon, Rahuri, Newasa, Rahata, Shevgaon and Pathardi tahsil.

\section{Reference}

Alaka Gadagil (1986): Annual and weekly analysis of rainfall and temperature for

Pune: A multiple time series approach. Inst. Indian Geographers.Vol.8.No.1.1986

Kale V. S. (1999): Long-period Fluctuations in Monsoon Floods in Deccan Peninsula,

India. Journal Geological Society of India, v. 53, pp. 5-15.
Kendall, M.G., (1975): Rank

Correlation Methods. Charles Graffin, London.

Mann, H.B. (1945): Nonparametric tests against trend. Econometrica13, 245-259.

IPCC (2007): Climate change 2007: synthesis report. In: R. K. Pachuri and A. Reisinger, Eds. Contribution of Working group 1, 2 and 3 to the fourth assessment report of the Intergovernmental panel on climate change (IPCC), Cambridge University press, Cambridge.

Raghvendra V. K., (1974): Trends and Periodicities of Rainfall in Sub division of

Maharashtra Indian journal of Meteorological Geophysics, v.25, pp. 197-20

Rathod, Muniyappa, I. and Aruchamy S. (2010): Spatial Analysis of Rainfall

Variation in Coimbatore District Tamilnadu using GIS. International Journal of Geomatics and Geosciences, 1(2), 106-118.

Sahu, R.K and Khare D. (2015): Spatial and Temporal Analysis of Rainfall Trend for 30 Districts of A Coastal State (Odisha) of India. International Journal of Geology, Earth \& Environmental Science 5, 40-53.

Sen P. K. (1968): Estimates of the regression coefficient based on Kendall's tau. J Am Stat Assoc. 1968; 39:1379-89. 